\title{
Vibrio alginolyticus in marine foods of animal origin from establishments in the port of Chabihau, Yucatan, Mexico
}

DOI: $10.46932 / \mathrm{sfjdv2n2-181}$

Received in: March 1st, 2021

Accepted in: May 30th, 2021

\section{José Franco-Monsrea}

Doctor en Ciencias Médicas \& Doctor en Nutrición

1Departamento de Salud y Desarrollo Comunitario. Universidad Intercultural Maya de Quintana Roo. Carretera Muna-Felipe Carrillo Puerto S/N, km. 137. CP. 77870. La Presumida, José María Morelos, Quintana Roo, México

E-mail: jose.franco@uimqroo.edu.mx

\section{Lidia Esther del Socorro Serralta-Peraza}

Maestra en Educación

1Departamento de Salud y Desarrollo Comunitario. Universidad Intercultural Maya de Quintana Roo. Carretera Muna-Felipe Carrillo Puerto S/N, km. 137. CP. 77870. La Presumida, José María Morelos, Quintana Roo, México

E-mail: lidia.serralta@uimqroo.edu.mx

\section{Javier Jesús Flores-Abuxapqui}

Doctor en Microbiología

2Departamento de Microbiología. Laboratorios Micro-Clin, S.A. de C.V. Mérida, Yucatán, México E-mail: javier.flores@correo.uady.mx

\begin{abstract}
To determine if the marine foods of animal origin that are sold in establishments in the port of Chabihau, Yucatan, Mexico, represent potential risk factors for the Vibrio alginolyticus species for the development of acute gastroenteritis, wound infection, ear infection and primary septicemia. Three hundred and ninety seafood samples were studied: [298 (76.41\%) raw, $8(2.05 \%)$ marinated without heat, $77(19.74 \%)$ partially cooked with heat and $7(1.79 \%)$ completely cooked with heat]. For the homogenization and enrichment of the samples, as well as for the isolation and identification of the Vibrio alginolyticus species, we proceeded according to the methodology described in the eighth edition of the Bacteriological Analytical Manual (FDA). The criteria used in conducting the hypothesis tests for the difference between two percentages was based on the recommendations made by Cochran. The prevalences obtained in raw seafood, marinated without heat, partially cooked with heat and completely cooked with heat were, respectively, $7.72 \%$ (23/298), $0.00 \%(0 / 8), 7.79 \%$ (6/77) and $0.00 \%(0 / 7)$. In 29 (7.44\%) samples an equal number of strains were isolated whose biochemical characteristics corresponded to the Vibrio alginolyticus species. It is concluded that raw seafood and partially cooked seafood represent potential risk factors for the Vibrio alginolyticus species for the development of acute gastroenteritis, wound infection, ear infection and primary septicemia.
\end{abstract}

Keywords. Vibrio alginolyticus, seafood, establishments. 


\section{INTRODUCTION}

In the second edition of the Bergey Manual of Systematic Bacteriology the Family Vibrionaceae belongs to Order XI (Vibrionales) of Class III (Gammaproteobacteria) of the Phylum BXII (Proteobacteria) of the Domain Bacteria. In turn, the Vibrionaceae Family is made up of the Vibrio, Allomonas, Catenococcus, Enterovibrio, Grimontia, Listonella, Photobacterium and Salinivibrio genera. Twelve of the sixty-six species of the genus Vibrio are considered human pathogens and are Vibrio alginolyticus, Vibrio carchariae, Vibrio cholerae, Vibrio cincinnatiensis, Vibrio damsela, Vibrio fluvialis, Vibrio furnissii, Vibrio hollisae, Vibrio metschnikovii, Vibrio mimicus, Vibrio parahaemolyticus, Vibrio parahaemolyticus, and Vibrio vulnificus (Garrity et al., 2004).

Vibrios are characteristically indigenous to marine, brackish, and estuarine habitats, and appear in large concentrations (blooms) when water temperatures rise $\left(17-20^{\circ} \mathrm{C}\right)$. At low temperatures the vibrios remain in the sediment of the seabed and the counts are usually lower than those necessary to cause infection. In temperate countries, vibrios are present in seawater throughout the year, although their concentration experiences a notable increase in warm months due to favorable ecological conditions and plankton, increasing their accumulation by filter feeders and other marine animals (West, 1989).

Vibrio alginolyticus species (Miyamoto et al., 1961), previously known as Vibrio parahaemolyticus biotype II, is the most halotolerant species; it supports a concentration of up to $10 \%$ of sodium chloride $(\mathrm{NaCl})$ and is the most abundant in seawater; it is very common in the marine habitat of temperate countries (Pérez et al., 1983). It causes gastrointestinal infections in man and occasionally extra-intestinal. It was not considered pathogenic until 1973 (Zen-Yogi et al., 1973) but, since then, the number of infectious processes in which it has been implicated has been increasing. It has been associated with enteritis (Nacescu et al., 1980), soft tissue infections (Rubín \& Tilton, 1975); abscesses (Opal \& Saxon, 1986), bacteremia (Bonner et al., 1983), conjunctivitis (Janda et al., 1986), peritonitis (Taylor et al., 1981), external conjunctivitis (Schmidt et al., 1979); and external otitis (García et al., 1993). In the case of otitis, there is often an underlying otic pathology (Hornstrup \& Gahm, 1993). Most of these infections are acquired by exposure to the marine environment or by contact with products derived from it. Vibrio alginolyticus is a ubiquitous organism in the sea and estuaries. Its distribution is worldwide; usually on the coasts of temperate countries; it is found in any marine organism such as fish, clams, oysters and corals, among others. It is a short, pleomorphic, large-negative bacillus, mobile by peritrichous and polar flagella. The signs and symptoms in humans are due to the ingestion of raw and/or insufficiently cooked marine products, or to damage to the skin when swimming in water where this microorganism is present. Vibrio alginolyticus is associated with acute gastroenteritis, wound infection, ear infection, and primary septicemia (Pavia et al., 1989). 
According to their method of preparation, seafood was classified into raw seafood, non-heat marinated seafood, partially cooked seafood with heat, and completely cooked seafood with heat. There were three varieties (crustaceans, mollusks and fish) and forty-two were the species studied (catfish, bosh or curucó; balá or whip ray, sea bream, boquinete, squid, shrimp, crab, snail, carp, gut dogfish, cherna pinta, chopa, chucumite, cuddly, sea bass, cuberita, smedregal, blackfin mackerel, crab, black horse mackerel, smooth, longtail, largemouth bass, manta ray, mussel, grouper, white mojarra, carp mojarra, tilapia mojarra, oyster, string vine, snapper mulatto, pejelagarto, wahoo, octopus, ray, snook, villajaiba blonde, salmon, sierra, tilapia and white trout).

The objective of the present investigation was to determine the prevalences of the Vibrio alginolyticus species in raw marine foods, marine foods marinated without heat, marine foods partially cooked with heat and marine foods completely cooked with heat. In other words, determining whether raw seafood, non-heat marinated seafood, partially heat-cooked seafood, and completely heat-cooked seafood represent potential risk factors for Vibrio alginolyticus for the development of acute gastroenteritis, wound infection, ear infection and primary septicemia (Pavia et al., 1989).

Null hypothesis $\left(\mathrm{H}_{0}\right)$. Raw seafood, marinated without heat, partially cooked with heat, and completely cooked with heat are not contaminated with Vibrio alginolyticus.

Alternative hypothesis $\left(\mathrm{H}_{1}\right)$. Raw seafood, marinated without heat, partially cooked with heat, and completely cooked with heat are contaminated with Vibrio alginolyticus.

\section{ANTECEDENTS}

The species Vibrio alginolyticus was isolated for the first time by Miyamoto et al.

Reyes-Velázquez et al., carried out an investigation whose objective was to determine the concentrations of the species Vibrio alginolyticus and Vibrio parahaemolyticus in Crassostrea virginica of the lagoon system of Mandinga, Veracruz, Mexico, and their relationship with salinity and temperature of the water. The times of greatest production and consumption of oysters were considered, that is, dry times and rainy seasons corresponding to 2008. Four sampling sites were selected and three samples were taken per site and per season, resulting in a total of twenty-four samples. Each sample consisted of thirty commercial-size microorganisms that were analyzed using the serial dilution technique. A biochemical characterization of the colonies found was made to determine the concentrations of Vibrio alginolyticus and Vibrio parahaemolyticus species in Most Probable Number per gram (MPN/g), whose values ranged from $<3$ to $150 \mathrm{MPN} / \mathrm{g}$. No correlations were found between the concentration of the Vibrio alginolyticus species and the temperature and salinity of the water in the rainy season. However, a positive correlation between the temperature and the concentration of the Vibrio parahaemolyticus species could be observed 
$(\mathrm{r}=0.69 ; \mathrm{p}<0.0500)$, while the correlation of the concentration of the Vibrio parahaemolyticus species and salinity was negative $(r=-0.68 ; \mathrm{p}<0.0500)$. The main contribution of this research work was the establishment of both safe zones and periods of oyster extraction. Vibrio alginolyticus is the most halotolerant species of the genus Vibrio since it supports concentrations of up to $10 \%$ of $\mathrm{NaCl}$ and is the most abundant species in seawater; it is very common in the oceanic habitat of temperate countries. The Vibrio alginolyticus species is a risk factor for the development of gastrointestinal infections in humans and, sporadically, for the development of extra-intestinal infections. It has low virulence and is frequently associated with other pathogenic microorganisms; its invasive power is low and the infections it causes are usually benign and self-limited. It was not considered a pathogenic species until 1973 but, since then, the number of infectious processes in which it has been implicated has been increasing. It has been associated with enteritis, soft tissue infections - especially in wounds and burns- and external otitis. Most of these infections are acquired by exposure to seawater or by contact with products derived from it. Clinically, the Vibrio alginolyticus species is associated with acute gastroenteritis, wound infection, ear infection, and primary septicemia.

Vibrio alginolyticus causes soft tissue and bloodstream infection; little systematically collected clinical and epidemiological information is available. In the USA, Vibrio alginolyticus infections are reported to the Cholera and Other Vibrio Illness Surveillance system. Using data from 1988 to 2012, we categorized infections using specimen source and exposure history, analyzed case characteristics, and calculated incidence rates using US Census Bureau data. Most (96\%) of the 1331 Vibrio alginolyticus infections were from coastal states. Infections of the skin and ear were most frequent (87\%); ear infections occurred more commonly in children, lower extremity infections more commonly in older adults. Most (86\%) infections involved water activity. Reported incidence of infections increased 12-fold over the study period, although the extent of diagnostic or surveillance bias is unclear. Prevention efforts should target waterborne transmission in coastal areas and provider education to promote more rapid diagnosis and prevent complications (Jacobs et al., 2017).

This study was conducted to determine the prevalence of Vibrio spp., in retail seafood in Berlin, Germany. A total of 160 raw seafood samples from supermarkets and seafood shops, consisting of shrimp $(n=80)$ and bivalves $(n=80)$, were investigated for the presence of Vibrio spp., using the International Organization for Standardization ISO/TS 21872 method and a multiplex PCR. The overall prevalence of Vibrio spp., in retail seafood was 55\% (95\% CI: 47.2 to 62.8\%). The prevalence of Vibrio spp., in shrimp was slightly higher than in bivalves ( 57.5 versus $52.5 \%$ ); however, the difference was not statistically significant. Vibrio alginolyticus was the most prevalent species (35.6\%), followed by Vibrio parahaemolyticus (27.5\%), Vibrio cholerae (6.3\%), and Vibrio vulnificus $(0.6 \%)$. None of the Vibrio 
parahaemolyticus $(\mathrm{n}=110)$ isolates encoded $\mathrm{tdh} /$ trh genes, whereas all Vibrio cholerae isolates $(\mathrm{n}=27)$ were lacking ctxA. Among the chilled samples $(\mathrm{n}=105)$, the prevalence of Vibrio spp., in unpacked samples was significantly higher than in packed samples $(p=0.006)$. Among the packed samples $(\mathrm{n}=55)$, no significant difference in the prevalence of Vibrio spp., was observed between chilled or frozen products. The results of this study indicated a high prevalence of Vibrio spp., in retail seafood in Germany; positive samples were detected in all types of seafood investigated. The detection of tdh/trh-negative Vibrio parahaemolyticus isolates should not be neglected because of previous findings on pathogenic strains lacking these virulence markers. Even though thorough cooking might limit the risk of foodborne illness caused by Vibrio, potential cross-contamination during preparation or consumption of raw and undercooked seafood might represent a risk of Vibrio infections (Vu et al., 2018).

Numerous prevalence studies of Vibrio spp., infection in fish have been extensively reported worldwide, including Malaysia. Unfortunately, information on the prevalence of Vibrio spp., in groupers (Epinephelus spp) is limited. In this study, groupers obtained from nine farms located at different geographical regions in Malaysia were sampled for the presence of pathogenic Vibrio spp., and their susceptibility profiles against seven antibiotics. Out of 270 grouper samples, 195 (72\%) were detected with the presence of Vibrio spp., Vibrio communis showed highest prevalence in grouper (28\%), followed by Vibrio parahaemolyticus (25\%), Vibrio alginolyticus (19\%), Vibrio vulnificus (14\%), Vibrio rotiferianus (3\%), Vibrio spp., (3\%), Vibrio campbellii (2\%), Vibrio mytili (2\%), Vibrio furnissii (2\%), Vibrio harveyi (1\%), Vibrio tubiashii (1\%), Vibrio fluvialis (0.3\%) and Vibrio diabolicus (0.3\%). Assessment on the antibiotic susceptibility profiles of the Vibrio spp., revealed that majority of the isolates were susceptible to tetracycline, streptomycin, erythromycin and bacitracin, but resistance to ampicillin, penicillin G and vancomycin. The mean MAR index of the Vibrio isolates was 0.51 , with $85 \%$ of the isolates showed MAR index value of higher than 0.2. Results indicate that the Vibrio spp., were continuously exposed to antibiotics. Furthermore, the plasmid profiles of Vibrio spp., showed that 38.7\% of the isolates harbored plasmid with molecular weight of more than $10 \mathrm{~kb}$, while $61.3 \%$ were without plasmid. During curing process, Vibrio spp., lost their plasmid, but remained resistant to ampicillin, penicillin $\mathrm{G}$, bacitracin and vancomycin while a few isolates remained resistant to erythromycin, streptomycin and tetracycline. The results suggested that the resistance to antibiotics in isolated Vibrio spp., might be due to chromosomal and plasmid borne. This study demonstrates the prevalence of Vibrio spp., in groupers and the distribution of multidrug resistance strains that could be of concern to the farmers in Malaysia. In addition, data from this study can be further used in fish disease management plan (Amalina et al., 2019). 
Infection of seafood with pathogenic species of the genus Vibrio causes human food-borne illnesses. This study was executed to examine the antimicrobial resistance phenotypes, biofilm-forming capability and virulence-associated genes of Vibrio from fish and shellfishes. Three hundred fresh water and marine fish and shellfish samples were collected from wet markets and supermarkets in Mansoura, Egypt. Bacteriological examination and PCR amplification identified 92 Vibrio spp., including 42 Vibrio parahaemolyticus and 50 Vibrio alginolyticus isolates from the examined fish and shellfish (infection rate: $30.67 \%$ ). However, Vibrio vulnificus was not found in this study. Vibrio spp., exhibited variable frequencies of antimicrobial resistance with higher percentages to ampicillin and penicillin. Multidrug resistance (MDR) was detected in 69.04 and 38\% of Vibrio parahaemolyticus and Vibrio alginolyticus respectively. PCR testing of virulence genes, tdh, trh and th revealed the presence of th and trh in 100 and $11.9 \%$ of Vibrio parahaemolyticus isolates respectively and none of Vibrio alginolyticus carried any of these genes. Biofilm-forming capability was displayed by $76 \%$ of Vibrio parahaemolyticus and $73.8 \%$ of Vibrio alginolyticus isolates. Both Vibrio parahaemolyticus and Vibrio alginolyticus showed no significant weak positive correlations $(r<0.4)$ between antimicrobial pairs belonging to different classes; however, a significant positive correlation $(p<0.0500)$ between trh and resistance to erythromycin $(\mathrm{r}=$ $0.45)$ and imipenem $(\mathrm{r}=0.38)$ was only identified in Vibrio parahaemolyticus. This study reports the existence of MDR strains of Vibrio parahaemolyticus and Vibrio alginolyticus from the common types of fishes and shellfishes in Egypt. Furthermore, the presence of virulence genes in these isolates and the ability to produce a biofilm in vitro pose potential health hazards to consumers. Frequent monitoring of seafood for the presence of Vibrio spp., and their antimicrobial susceptibility, virulence determinants and biofilm-forming capability is important for assessing the risk posed by these organisms to the public and for improving food (Sadat et al., 2020).

Seafood samples obtained in seafood markets and supermarkets at 11 sites selected from four states in Malaysia were examined for the presence of nine potentially pathogenic species from the genus Vibrio between July 1998 and June 1999. We examined 768 sample sets that included shrimp, squid, crab, cockles, and mussels. We extensively examined shrimp samples from Selangor State to determine seasonal variation of Vibrio populations. Eight potentially pathogenic Vibrio species were detected, with overall incidence in the samples at $4.6 \%$ for Vibrio cholerae, $4.7 \%$ for Vibrio parahaemolyticus, $6.0 \%$ for Vibrio vulnificus, $11 \%$ for Vibrio alginolyticus, $9.9 \%$ for Vibrio metschnikovii, $1.3 \%$ for Vibrio mimicus, $13 \%$ for Vibrio damsela, $7.6 \%$ for Vibrio fluvialis, and 52\% for a combined population of all of the above. As many as eight Vibrio species were detected in shrimp and only four in squid and peel mussels. The overall percent incidence of any of the eight vibrios was highest (82\%) in cockles (Anadara granosa) among the seafoods examined and was highest (100\%) in Kuching, Sarawak State, and lowest (25\%) in 
Penang, Pulau Penang State, among the sampling sites. Of 97 strains of Vibrio cholerae isolated, one strain belonged to the 01 serotype and 14 to the 0139 serotype. The results indicate that the various seafood markets in Malaysia are contaminated with potentially pathogenic Vibrio species regardless of the season and suggest that there is a need for adequate consumer protection measures (Elhadi et al., 2004).

\section{MATERIAL AND METHODS}

\section{-Epistemological approach}

Quantitative approach, probabilistic approach or positivist approach (Hernández-Sampieri et al., 2006).

\section{-Study design}

Descriptive, cross-sectional observational study with no directionality and prospective temporality (Hernández-Ávila, 2007).

\section{-Study universe}

The study was carried out in the total of samples of the twenty one establishments specialized in the sale of seafood for human consumption in the port of Chabihau, Yucatan, Mexico, in the period from June 1, 2019 to May 31, 2020.

Chabihau, Yucatan, Mexico (Figure 1). Chabihau is a Yucatan fishing port in Mexico belonging to the municipality of Yobain and located on the northern coast of the Yucatan peninsula. It is located on the northern coast of the state of Yucatan, $58 \mathrm{~km}$ east of the city and port of Progreso de Castro, between the town of San Crisanto (Sinanche municipality) to the East and Santa Clara (Dzidzantun municipality) to the West and directly to the North connected with a paved highway with Yobain, the municipal seat of the homonymous municipality. The term Chabihau in the Mayan language means "where the anteater" (Chab) "opens the way" (haw). It is a patronymic and toponymic (Barrera-Vázquez, et al., 1980). There are no recorded data on the foundation of the current population of Chabihau, although it is known that there was a Mayan occupation before the conquest of Yucatan in the region, which belonged to the chiefdom or jurisdiction of Ah Kin Chel. Towards 1825 the town belonged to the Partido de la Costa whose head was Izamal. Later, Chabihau became part of the jurisdiction of Dzilam Gonzalez. Finally, as of 1921, the port is part of the municipality of Yobain. Ecotourism has become one of the main activities in the region. The entire area of beaches on the north coast of the peninsula is a natural attraction that attracts a large number of local and foreign tourists. There is a small archaeological site of the preHispanic Mayan civilization called Chabihau near the town (Casares G. Cantón et al., 1998). 
Figure 1. Chabihau, Yucatan, Mexico

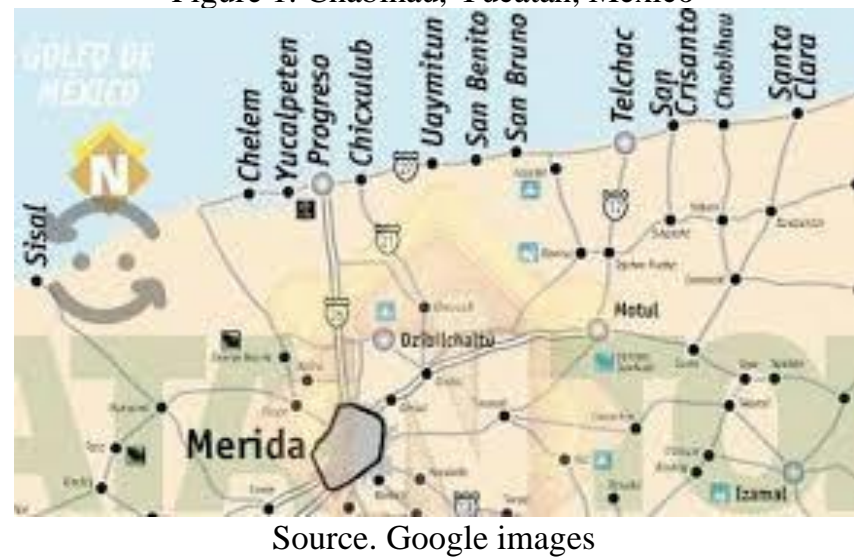

\section{-Operational definitions of variables}

* Establecimientos. Establecimientos que expenden alimentos marinos de origen animal para consumo humano y que cuentan con licencia sanitaria expedida por los Servicios de Salud del estado de Yucatán (Franco \& Flores, 1988);

Alimento marino. Cualquier producto de origen animal procedente del mar que proporcione al organismo humano elementos para su nutrición (Franco \& Flores, 1988);

Alimento marino crudo. Cualquier producto de origen animal procedente del mar que proporcione al organismo humano elementos para su nutrición y que en el momento del muestreo haya sido encontrado en su estado natural (Franco \& Flores, 1988);

Alimento marino marinado sin calor. Cualquier producto de origen animal procedente del mar que proporcione al organismo humano elementos para su nutrición y que en el momento del muestreo haya sido encontrado cocido utilizando la acción del ácido del jugo de limón, del ácido del jugo de naranja y del vinagre, entre otros (Franco \& Flores, 1988);

Alimento marino parcialmente cocido con calor. Cualquier producto de origen animal procedente del mar que proporcione al organismo humano elementos para su nutrición y que en el momento del muestreo haya sido encontrado preparado de la siguiente manera: a) calentar agua hasta ebullición; b) apagar la fuente de calor y adicionar el alimento marino; c) dejar "ablandar" el alimento marino en el agua caliente durante al menos 5 min; y d) transferir el alimento marino a un recipiente dejándolo reposar hasta enfriamiento. Este alimento se encuentra listo para ser utilizado en la preparación de cebiches y/o cócteles (Franco \& Flores, 1988) y;

Alimento marino completamente cocido con calor. Cualquier producto de origen animal procedente del mar que proporcione al organismo humano elementos para su nutrición y que en el momento del muestreo haya sido encontrado cocido utilizando la acción del calor (asado a la parrilla, frito y vapor de agua, entre otros) (Franco \& Flores, 1988). 


\section{-Techniques and procedures}

A first visit was made to each of the establishments specialized in the sale of seafood for human consumption and a list of one hundred ninety six samples was compiled which, according to their method of preparation, were classified into raw seafood, non-heat marinated seafood, partially cooked seafood with heat and completely cooked seafood with heat. The establishments received a second visit (in the period from June 1, 2019 to May 31, 2020) during which the samples were obtained.

Each sample weighed approximately $50 \mathrm{~g}$; individually stored in sterile polyethylene bag (Ziploc); it was kept refrigerated; and it was sent for processing to Laboratorios Micro-Clin, S.A. de C.V., from the city of Merida. The processing of the samples was carried out in the period from June 1, 2019 to May $31,2020$.

For the homogenization and enrichment of each sample, as well as for the isolation and identification of the Vibrio alginolyticus species, we proceeded according to the methodology described in the eighth edition of the Bacteriological Analytical Manual (FDA) (Elliot et al., 1998).

* Homogeneización. Con la ayuda de un bisturí estéril y de una pinza anatómica estéril con diente se pesaron $25 \mathrm{~g}$ en una caja estéril de Petri; se transfirieron a un vaso estéril de licuadora de $200 \mathrm{ml}$ de capacidad; se agregaron $125 \mathrm{ml}$ de caldo peptonado con $3 \%$ de $\mathrm{NaCl}$; y se licuó el contenido a baja velocidad durante $1 \mathrm{~min}$;

* Enriquecimiento. Se transfirió $1 \mathrm{ml}$ de la suspensión resultante a un tubo de cultivo conteniendo $9 \mathrm{ml}$ de caldo peptonado con $3 \%$ de $\mathrm{NaCl}$; y se incubó a $35-37^{\circ} \mathrm{C}$ durante $18-24 \mathrm{~h}$;

* Aislamiento. Del crecimiento en la superficie se resembró por estrías en una placa de agar Tiosulfato-Citrato-sales Biliares-Sacarosa (agar TCBS) y en una placa de agar modificado CelobiosaPolimixina B-Colistina (agar mCPC); se incubó a 35-37 $\mathrm{C}$ durante $18-24 \mathrm{~h}$; de las colonias pigmentadas de color verde que desarrollaron se hicieron frotes para teñir por el método de Gram; cuando las colonias estuvieron constituidas por bacilos gram-negativos curvos o ligeramente curvos se realizó la prueba de la oxidasa como prueba presuntiva;

* Identificación. A las colonias que pasaron satisfactoriamente la prueba presuntiva, es decir, que resultaron positivas a la prueba de la oxidasa, se les realizaron las siguientes pruebas bioquímicas complementarias: producción de arginina deshidrolasa; descarboxilación de la ornitina; descarboxilación de la lisina; crecimiento en agar nutritivo con $0 \% \mathrm{de} \mathrm{NaCl}$; crecimiento en agar nutritivo con $3 \%$ de $\mathrm{NaCl}$; crecimiento en agar nutritivo con $6 \%$ de $\mathrm{NaCl}$; crecimiento en agar nutritivo con $8 \%$ de $\mathrm{NaCl}$; crecimiento en agar nutritivo con $10 \%$ de $\mathrm{NaCl}$; crecimiento a $42^{\circ} \mathrm{C}\left(107.6^{\circ} \mathrm{F}\right)$; metabolismo fermentativo de la sacarosa; metabolismo fermentativo de la D-celobiosa; metabolismo fermentativo de la lactosa; metabolismo fermentativo de la arabinosa; metabolismo fermentativo de la D-manosa; 
metabolismo fermentativo del D-manitol; hidrólisis del o-nitro- $\square-\mathrm{D}-$ galactopiranósido (ONPG); reacción de Voges-Proskauer; y licuefacción de la gelatina.

Table 1 shows the differential characteristics or biochemical properties of the Vibrio alginolyticus species associated with clinical syndromes related to the consumption of fish and shellfish.

Table 1. Vibrio alginolyticus according to differential characteristics or biochemical properties.

\begin{tabular}{|c|c|}
\hline $\begin{array}{c}\text { Differential characteristics o biochemical } \\
\text { properties }\end{array}$ & Vibrio alginolyticus \\
\hline 1. TCBS agar & $\mathrm{A}$ \\
\hline 2. mCPC agar & $\mathrm{NG}$ \\
\hline 3. Oxidase & + \\
\hline 4. Production of arginine dehydrolase & - \\
\hline 5. Decarboxylation of ornithine & + \\
\hline 6. $\quad$ Decarboxylation of lysine & + \\
\hline 7. Growth in nutrient agar with $0 \% \mathrm{NaCl}$ & - \\
\hline 8. Growth in nutrient agar with $3 \% \mathrm{NaCl}$ & + \\
\hline 9. Growth in nutrient agar with $6 \% \mathrm{NaCl}$ & + \\
\hline 10. Growth in nutrient agar with $8 \% \mathrm{NaCl}$ & + \\
\hline 11. Growth in nutrient agar with $10 \% \mathrm{NaCl}$ & + \\
\hline 12. Growth at $42^{\circ} \mathrm{C}\left(107.6^{\circ} \mathrm{F}\right)$ & + \\
\hline 13. Fermentative metabolism of sucrose & + \\
\hline 14. Fermentative metabolism of D-cellobiose & - \\
\hline 15. Fermentative metabolism of lactose & - \\
\hline 16. Fermentative metabolism of arabinose & - \\
\hline 17. Fermentative metabolism of D-mannose & + \\
\hline 18. Fermentative metabolism of D-mannitol & + \\
\hline 19. ONPG & - \\
\hline 20. Voges-Proskauer reaction & + \\
\hline 21. Gelatin liquefaction & + \\
\hline 22. Fermentation of myo-inositol & - \\
\hline
\end{tabular}

$\mathrm{A}=$ Yellow pigmented colonies; and $\mathrm{NG}=$ No growth

Source. West et al., 1986; Elliot et al., 1998

Two $\mathrm{x}$ two contingency tables were constructed from which prevalences were calculated. As a hypothesis test or test of statistical significance, the Mantel and Haenszel Chi-Square statistic $\left(\mathrm{x}^{2} \mathrm{M}-\mathrm{H}\right)$ was used. The Epi Info program for Windows, Version 7.1.5.2, was used to obtain the values of the $\mathrm{x}^{2} \mathrm{M}-\mathrm{H}$ statistic and the probabilities $(p)$. The criterion applied in carrying out the hypothesis tests for the difference between two percentages was based on the recommendations made by Cochran (1954): 1 . When $\mathrm{N}>40$ use the $\mathrm{x}^{2} \mathrm{M}-\mathrm{H}$ test; 2 . When $20 \leq \mathrm{N} \leq 40$ use the $\mathrm{x}^{2} \mathrm{M}-\mathrm{H}$ test if, and only if, all expected frequencies are $\geq 5$; if in any cell there is at least an expected frequency $<5$, then use the Fisher's exact probability test (PPEF); and 3. When $\mathrm{N}<20$ use the PPEF.

$$
\begin{gathered}
\mathrm{X}^{2} \mathrm{M}-\mathrm{H}=\Sigma(|\mathrm{O}-\mathrm{E}|-1 / 2)^{2} / \mathrm{E} \\
\mathrm{PPEF}=(\mathrm{A}+\mathrm{B}) !(\mathrm{C}+\mathrm{D}) !(\mathrm{A}+\mathrm{C}) !(\mathrm{B}+\mathrm{D}) ! / \mathrm{N} ! \mathrm{A} ! \mathrm{B} ! \mathrm{C} ! \mathrm{D} !
\end{gathered}
$$


The Cornfield estimation interval was constructed at the $95 \%$ confidence level for the percentage in the population of seafood with the species Vibrio alginolyticus (Daniel, 1979).

$\mathrm{p}-\mathrm{Z} \sigma \mathrm{p} \leq \mathrm{P} \leq \mathrm{p}+\mathrm{Z} \sigma \mathrm{p}$

\section{-Data processing}

In the elaboration stage, the data were reviewed (information quality control); classified (on a qualitative scale); computerized (the IBM SPSS Statistics software for Windows, Version 22) was used; presented (in Tables and in Graphs); and summarized (the corresponding summary measures were used for data classified on a qualitative scale). In the analysis and interpretation stages, the data were analyzed and interpreted, respectively.

\section{RESULTS}

One hundred ninety six seafood samples were studied and classified according to their preparation methods into raw seafood, non-heat marinated seafood, partially heat-cooked seafood, and completely heat-cooked seafood.

The eight differential key tests to divide the twelve clinically significant species of the genus Vibrio into six groups are presented in Table 2. The species investigated in the present work belongs to Group 6 (negative production of arginine dehydrolase and positive decarboxylation of lysine).

Table 2. Eight differential key tests to divide the twelve clinically significant Vibrio species into six groups.

\begin{tabular}{|c|c|c|c|c|c|c|c|c|c|c|c|c|}
\hline \multirow[b]{2}{*}{$\begin{array}{c}\text { Differential key } \\
\text { tests }\end{array}$} & \multicolumn{2}{|c|}{ Group 1} & \multirow{2}{*}{ 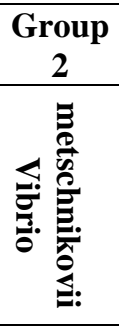 } & \multirow{2}{*}{ 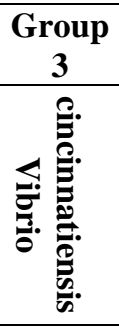 } & \multirow{2}{*}{ 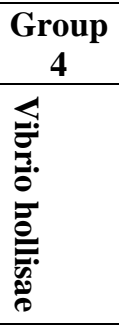 } & \multicolumn{3}{|c|}{ Group 5} & \multicolumn{4}{|c|}{ Group 6} \\
\hline & 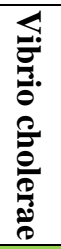 & 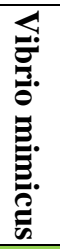 & & & & 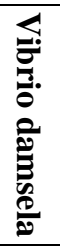 & 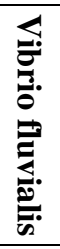 & 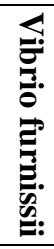 & 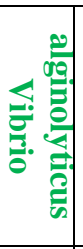 & $\begin{array}{r} \\
\\
\end{array}$ & ¿气 & 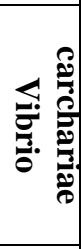 \\
\hline $\begin{array}{l}\text { 1. } \begin{array}{l}\text { Growth in } \\
\text { nutrient agar } \\
\text { with } 0 \% \mathrm{NaCl}\end{array} \\
\end{array}$ & + & + & & & & & & & & & & \\
\hline $\begin{array}{ll}\text { 2. } & \text { Growth in } \\
\text { nutrient agar } \\
\text { with } 1 \% \mathrm{NaCl} \\
\end{array}$ & + & + & & & & & & & & & & \\
\hline 3. Oxidase test & & & - & & & & & & & & & \\
\hline $\begin{array}{ll}4 . & \text { Reduction of } \\
\text { nitrates }\left(\mathrm{NO}_{3}\right) \mathrm{a} \\
\text { nitrites }\left(\mathrm{NO}^{2}\right) \\
\end{array}$ & & & - & & & & & & & & & \\
\hline $\begin{array}{ll}\text { 5. } & \begin{array}{l}\text { Fermentation of } \\
\text { myo-inositol }\end{array}\end{array}$ & & & & + & & & & & & & & \\
\hline $\begin{array}{l}\text { 6. } \begin{array}{l}\text { Production of } \\
\text { arginine } \\
\text { dehydrolase }\end{array} \\
\text { dehydr. }\end{array}$ & & & & & - & + & + & + & - & - & - & - \\
\hline $\begin{array}{l}\text { 7. Decarboxylation } \\
\text { of lysine }\end{array}$ & & & & & - & & & & + & + & + & + \\
\hline
\end{tabular}


8. Decarboxylation of ornithine

Source. Kelly et al., 1991

Table 3 shows the absolute and relative frequencies of the Vibrio alginolyticus species in seafood according to preparation methods. Five $(3.36 \%)$ of the 149 samples labeled raw seafood, $0(0.00 \%)$ of the 4 samples labeled non-heat marinated seafood, 2 (5.13\%) of the 39 samples labeled partially heat-cooked seafood, and $0(0.00 \%)$ of the 4 samples labeled as completely heat cooked seafood had positive results. The global prevalence of the Vibrio alginolyticus species was $3.57 \%(7 / 196)$.

The Cornfield estimation interval at the $95 \%$ confidence level for the percentage in the population of seafood with the species Vibrio alginolyticus was $-10.18 \% \leq \mathrm{P} \leq 17.32 \%$.

In this estimation interval is zero (0), which agrees with the hypothesis test in the sense that there is no statistically significant difference between the prevalence of raw seafood $(3.36 \%)$ and the prevalence of raw seafood. partially cooked seafood with heat (5.13\%).

Table 3. Absolute frequencies and relative frequencies of the Vibrio alginolyticus species in seafood according to preparation methods. Chabihau, Yucatan, Mexico. June/1/2019-May/31/2020.

\begin{tabular}{|l|r|r|r|}
\hline \multirow{2}{*}{ Preparation methods } & \multicolumn{2}{|c|}{ Vibrio alginolyticus } & \multirow{2}{*}{ Totals } \\
\cline { 2 - 3 } & Positive samples & Negative samples & $298(100.00 \%)$ \\
\hline 1. Raw & $23(7.72 \%)$ & $275(92.28 \%)$ & $8(100.00 \%)$ \\
\hline $\begin{array}{l}\text { 2. } \\
\text { harinated without }\end{array}$ & $0(0.00 \%)$ & $8(100.00 \%)$ & $77(100.00 \%)$ \\
\hline $\begin{array}{l}\text { 3. } \\
\text { Partially cooked } \\
\text { with heat }\end{array}$ & $6(7.79 \%)$ & $71(92.21 \%)$ & $7(100.00 \%)$ \\
\hline $\begin{array}{l}\text { 4. } \begin{array}{l}\text { Completely cooked } \\
\text { with heat }\end{array} \\
\text { Totals }\end{array}$ & $0(0.00 \%)$ & $7(100.00 \%)$ & $\mathbf{3 9 0}(\mathbf{1 0 0 . 0 0 \%})$ \\
\hline
\end{tabular}

Source. Own elaboration

\section{DISCUSSION}

The highest prevalence $(7.79 \% ; 6 / 77)$ was observed in seafood partially cooked with heat. Sea foods partially cooked with heat are those that at the time of sampling were cooked through a "softening" process in which hot water is used for at least five minutes. This result does not correspond to the expected one and the observed prevalence can be explained either because the procedure used to "soften" the food is not enough to destroy the microorganism - an assumption that is supported by the study of Peffers $e t$ al., (1973) in which the viability of the microorganism is reported after having kept a crustacean in boiling water for five min prior inoculation of $0.1 \mathrm{ml}$ of culture broth-, or, because the food could have been contaminated by the handler after the process of "softening" due to cross contamination in the kitchens, or, through the anus-hand-food mechanism due to being an asymptomatic carrier -supposition that is 
supported by the study by Franco \& Flores (1988) in which 3.85\% is reported of seafood handlers who excrete the microorganism in their feces.

Second is the prevalence $(7.72 \% ; 23 / 298)$ observed in raw seafood. Raw marine foods are those that were in their natural state at the time of sampling. Consequently, this result corresponds to that expected because the probability of insulation is high when the food has not been exposed to the action of heat.

No statistically significant difference was found when comparing the relative frequency or rate of positivity observed in partially cooked seafood with heat $(7.79 \%)$ versus the relative frequency or rate of positivity observed in raw seafood $(7.72 \%): \mathrm{x}^{2}{ }_{\mathrm{M}-\mathrm{H}}(\alpha=0.0500 ; \mathrm{gl}=1)<3.8416 ; p>0.0500$.

\section{CONCLUSIONS}

Sea foods partially cooked with heat and raw seafood represent potential risk factors for Vibrio alginolyticus species for the development of acute gastroenteritis, wound infection, ear infection, and primary septicemia.

Finding partially heat-cooked seafood contaminated by the species Vibrio alginolyticus suggests the existence of asymptomatic carrier seafood handlers. The foregoing should occupy the attention of the corresponding authorities in order to continue carrying out related studies in this regard.

Likewise, if to date it has not been considered a public health problem, it is convenient to keep it in mind in order to prevent health problems that could at some point affect the health of the population of the port of Chabihau, Yucatan, Mexico.

The results obtained in the present work are consistent with the results obtained in studies carried out by other authors (Elhadi et al., 2004; Jacobs et al., 2017; Vu et al., 2018; Amalina et al., 2019; Sadat et al., 2020).

\section{ACKNOWLEDGEMENTS}

Thanks our gratitude to the Universidad Intercultural Maya de Quintana Roo and the Servicios de Salud de Yucatan for each and every one of the facilities provided to carry out this work. 


\section{REFERENCES}

Amalina NZ, Santha S, Zulperi D, Amal MNA, Yusof MT, Zamri-Saad M, Ina-Salwany MY. 2019. Prevalence, antimicrobial susceptibility and plasmid profiling of Vibrio spp., isolated from cultured groupers in Peninsular Malaysia. BMC Microbiol. 19(1):251. doi: 10.1186/s12866-019-1624-2. PMID: 31711432; PMCID: PMC6849203.

Bonner Jr, Cocker AS, Berryman CR, Pollock HM. 1983. Spectrum of Vibrio infections in a gulf coast community. Ann Intern Med. 99:464-469.

Casares G. Cantón R, Duch-Colell J, Kolpa A, Zavala-Vallado S. 1998. Yucatán en el tiempo. Mérida, Yucatán. ISBN 9709071041.

Cochran WG. 1954. Some methods for strengthening the common $\mathrm{x}^{2}$ tests. Biometrics. 10:417-451.

Daniel WW. 1979. Bioestadística. Base para el Análisis de las Ciencias de la Salud. México, D.F.: Editorial Limusa. 91-92, 143-144.

Elhadi N, Radu S, Chen CH, Nishibuchi M. 2004. Prevalence of potentially pathogenic Vibrio species in the seafood marketed in Malaysia. J Food Prot. 67(7):1469-1475. doi: 10.4315/0362-028x-67.7.1469. PMID: 15270503.

Elliot EL, Kaysner CA, Jackson L, Tamplin ML. 1998. Vibrio cholerae, Vibrio parahaemolyticus, Vibrio vulnificus, and other Vibrio spp. Chapter. 9. In Food and Drug Administration Bacteriological Analytical Manual, 8th ed. (revision A), (CD-ROM version). Merker RL. (Ed.). AOAC International, Gaithersburg, MD.

Franco-Monsreal J, Flores-Abuxapqui JJ. 1988. Prevalencia de Vibrio parahaemolyticus en productos marinos y en heces de manipuladores de alimentos. Rev Lat-amer Microbiol. 30:223-227.

García-Martos P, Benjumeda M, Delgado D. 1993. Otitis externa por Vibrio alginolyticus: descripción de cuatro casos. Acta Otorrinolaring Esp. 44:55-57.

Garrity GM, Bell JA, Lilburn TG. 2004. Taxonomic Outline of the Praryotes. Bergey's Manual of Systematic Bacteriology. 112-113.

Hernández-Ávila M. 2007. Epidemiología. Diseño y Análisis de Estudios. México, Editorial Médica Panamericana.

Hernández-Sampieri R, Fernández-Collado C, Baptista-Lucio P. 2006. Metodología de la Investigación. México, McGraw-Hill/Interamericana Editores, S.A. de C.V.

Hornstrup MK, Gahm-Hansen B. 1993. Extraintestinal infections caused by Vibrio parahaemolyticus and Vibrio alginolyticus in a Danish county, 1987-1992. Stand J Infect Dis. 25:735-740.

Jacobs-Slifka KM, Newton AE, Mahon BE. 2017. Vibrio alginolyticus infections in the USA, 19882012. Epidemiol Infect. 145(7):1491-1499. doi: 10.1017/S0950268817000140. Epub. PMID: 28202099.

Janda JM, Brenden R, Debenedetti JA, Constantino MO, Robín T. 1986. Vibrio alginolyticus bacteriemia in an immunocompromised patient. Diagn Infect Dis. 5:337-340. 
Kelly MT, Hickman-Brenner FW, Farmer JJ III. 1991. Vibrio: In Balows A, Hausler WJ, Herrmann KL, Isenberg HD, Shadomy HJ (Editors). Manual of Clinical Microbiology ( $5^{\mathrm{a}}$ Ed.). Washington, D.C.: American Society for Microbiology. 389.

Miyamoto Y, Nakamuma K, Takizawa K. 1961. Pathogenic halophiles. Proposals of a new genus "Oceanomonas" and of the amended species names. Japanese Journal of Microbiology. 5(4):477-486.

Nacescu N, Ciufecu C, Florescu D. 1980. Vibrio alginolyticus enteritis. Ann Sclavo. 22:169-172.

Opal SM, Saxon JR. 1986. Intracranial infection by Vibrio alginolyticus following injure in salt water. J Clin. 23:373-374.

Pavia AT, Bryan JA, Maher KL, HEster TR Jr., Farmer JJ III. 1989. Vibrio carchariae infection after a shark bite. Ann Intern Med. 111:85-86.

Peffers A, Bayley J, Barrow GI, Hobbs BC. 1973. Vibrio parahaemolyticus gastroenteritis and international air travel. The Lancet. 1:143-145.

Pérez-Trallero E, Urbieta-Egaña M, Gasser-Laguna I, Fernández-Pérez F. 1983. Vibrio alginolyticus. Estudio comparativo entre cepas de procedencia humana y aisladas del medio ambiente. Clin. 1:102-106.

Reyes-Velázquez C, Castañeda-Chávez MR, Landeros-Sánchez C, Galaviz-Villa I, Lango-Reynoso Fabiola, Minguez-Rodríguez MM, Nikolskii-Gavrilov I. (2010). Pathogenic vibrios in the oyster Crassostrea virginica in the lagoon system of Mandinga, Veracruz, Mexico. Hidrobiológica. 20(3):238245.

Rubín SJ, Tilton RC. 1975. Isolation of Vibrio alginolyticus from infections. J Clin. 2:556-558.

Sadat A, El-Sherbiny H, Zakaria A, Ramadan H, Awad A. 2020. Prevalence, antibiogram and virulence characterization of Vibrio isolates from fish and shellfish in Egypt: a possible zoonotic hazard to humans. J Appl Microbiol. doi: 10.1111/jam.14929. Epub ahead of print. PMID: 33187023.

Schmidt U, Chmel H, Cobbs C. 1979. Vibrio alginolyticus infections in humans. J Clin. 10:666-668.

Taylor R, McDonald M, Russ G, Carson M, Lukaczynshi E. 1981. Vibrio alginolyticus peritonitis associated with ambulatory peritoneal dialysis. Br Med J. 283:275.

Vu TTT, Alter T, Huehn S. Prevalence of Vibrio spp., in Retail Seafood in Berlin, Germany. J Food Prot. 2018. 81(4):593-597. doi: 10.4315/0362-028X.JFP-17-366. PMID: 29517352.

West PA, Brayton PR, Bryant TN, Colwell RR. 1986. Numerical taxonomy of vibrios isolated from aquatic environments. Int J Syst Bacteriol. 36:531-543.

West PA. 1989. The human pathogenic vibrios -a public health update with environmental perspectives. Epidemiology and Infection. 103(1):1-34.

Zen-Yogi H, Leclair RA, Ohta K, Montague TS. 1973. Comparison of Vibrio parahaemolyticus cultures isolates in the United States with those isolates in Japan. J Infect Dis. 127:237-241. 